\title{
A sustainable energy-system in Latvia
}

\author{
L.H. Rasmussen* \\ Department of Development and Planning, Aalborg University, Fibigerstraede 13, \\ 9220 Aalborg O, Denmark
}

Accepted 13 November 2002

\begin{abstract}
This paper presents some of the problems in the Latvian energy-system, the Latvian economy and how a sustainable restructuring of the energy system with renewable energy, cogeneration and the production of energy technology can help solve some of the problems. Latvia has economic growth but a negative trade-balance. With this in mind, it is important that Latvia is able to meet the challenge and use the economic development to develop a sustainable energy-system and a sounder trade-balance. A combination of energy planning, national economy and innovation processes in boiler companies will form the reflective approach of this paper to the future of energy supplies in Latvia.
\end{abstract}

(C) 2003 Elsevier Ltd. All rights reserved.

Keywords: Latvia; Energy; Technology; Economy; Energy planning

\section{Energy-system background}

Latvia is one of the three Baltic states which were formerly part of the Soviet Union. Latvia regained independence in 1991, after having been occupied for 40 years. In the Soviet period, the energy supply in the Baltic republics was planned for the region as a whole. This has meant that today there are considerable differences between the Baltic countries now that each country has to consider its own energy supply. Estonia is supplied with electricity mainly by the utilisation of oil shale and Lithuania is supplied with electricity from nuclear power [5]. The hydro power plants in Latvia were used to regulate the electricity in the whole Baltic region [13]. Today Estonia and Lithuania have excess electricity production capacity and Latvia

* Tel.: + 45-9635-8299; fax: +45-9815-3788.

E-mail address: holmberg@plan.auc.dk (L.H. Rasmussen). 
has insufficient capacity to meet its own demand. This makes Latvia an interesting example because the country has the opportunity to build a sustainable energy-system when coping with the capacity shortage.

Latvia has some electricity production from co-generation plants and some from hydro-power plants. However, the production of electricity from the hydro-power plants fluctuates a great deal from year-to-year. The rest of the electricity for consumption is imported from the neighbouring countries [1].

A dependence on imported electricity can be a problem for two reasons. Firstly there is the question of security of supply. Even though Estonia and Lithuania today have excess electricity-production capacity and therefore are willing to sell at a low price, this might not be the case in the future. Secondly, there is an economic question linked to the supply security. If for some reason it comes to the point where the neighbouring countries electric capacity goes down, then the price of electricity exported to Latvia will go up. This means that Latvia should consider restructuring the energy system to include more electricity-generating capacity.

\section{The energy-system today}

As a starting point for the energy-system analysis and the examination of the possibilities for the future, we must begin with the present situation.

Latvenergo is the national energy company which produces most of the electricity in Latvia. Today the company has an electricity-generating capacity of $2046 \mathrm{MW}$. Approximately one fourth of this is from two co-generation plants and the rest is divided among three hydro-power plants placed on the river Daugava. In the year 2000, Latvenergo produced $97 \%$ of the electricity generated in Latvia [11]. The rest was produced by privately-owned electricity-generating units.

Because of the hydro-power stations, the production of electricity in Latvia changes every year according to the level of precipitation. This means that the annual production from the hydro-power plants can vary between 1800 and 4600 GWh [11]. The production of electricity from the co-generation plants is to a large extent determined by the heat demand. Due to the fluctuating nature of the domestic electricity-production, Latvia imports the remaining part of the electricity. Imports of electricity have varied between $83 \%$ (1996) and 20\% (1998) of the final consumption of electricity during recent years [1].

One of the two large co-generation plants uses natural gas, residual fuel oil and peat and the other uses natural gas and residual fuel oil. There are plans to renovate the first plant and replace the generating unit with a modern gas/steam cycle cogeneration unit. The second plant has to some degree already been renovated and the efficiency has improved [11].

Seventy percent of the heat in Latvia is supplied from district-heating systems either from heat plants or co-generation [13]: $37 \%$ of the district heating in 2000 in Latvia was produced by means of co-generation plants. This means that $63 \%$ of the district heating is produced in heat plants - also called boiler houses [1]. This means that there is potential to replace some of the heat plants with co-generation units. 
(Eighty percent of the district heating in Denmark is supplied from CHP [4]. Denmark is to a large extent similar to Latvia in relation to population and geographic conditions. A major difference is that Denmark has had an energy-reduction policy since the mid 70s.)

There are a number of problems in the Latvian district-heating systems. The efficiency in heat plants and district-heating systems is low. There are losses both in the pipes and in the plants themselves. The plants were constructed in the years from 1960 to 1990 and many of these now need replacement or reconstruction. Due to the decline in the heat demand, the plants are working below their nominal capacities. This also means that the efficiency is lower. Now the prices are based on a market system and have increased. This means that many people in Latvia have difficulties paying their heat bills and they are therefore considering disconnecting from the district-heating system and using individual heat solutions [13]. To support this is the fact that even though the final consumption of electricity in 2000 was $8 \%$ larger than in 1996, the heat consumption produced as district heating was $46 \%$ lower [1].

Another issue to be considered when analysing the possibilities is the present use of fuels and the potential for the future. Latvia has no real fossil-fuels of its own and therefore the consumption must be imported. However Latvia uses the domestic renewable-energy resources hydro-power and biomass. The use of wind power and solar is insignificant. Latvia also utilises the domestic energy-source peat, which counted for $1.6 \%$ of the gross energy-consumption in 2000 [1]. However, peat cannot be counted as a renewable energy source. Even though it takes only a few hundred years for peat to build up, presently there is no renewal of the energy source after it has been extracted from the bogs.

The use of primary energy for the gross energy-consumption in Latvia can be seen in Table 1. The share of renewable energy in the gross energy-consumption is made up of fuelwood and hydro energy. That means that there was a total of $27.9 \%$ of the gross energy-consumption from renewable-energy sources in Latvia in the year 2000.

The most important domestic renewable-energy resource in Latvia is biomass in the form of fuelwood: $45 \%$ of Latvia is covered with woods and this substantial area makes wood a significant potential as a resource for the future energy supplies. According to Shipkovs et al. [17], the potential for firewood production is 10.5 million $\mathrm{m}^{3}$ per year, which can be utilised without damage to the environment. Much wood is left in the woods in spite of regulations prohibiting this practice [17]. The utilisation of wood for energy purposes was 4 million $\mathrm{m}^{3}$ in 1995 [17]. However,

Table 1

Gross energy-consumption in Latvia in the year 2000

\begin{tabular}{|c|c|c|c|c|c|c|c|c|c|}
\hline & $\begin{array}{l}\text { Natural } \\
\text { gas }\end{array}$ & $\begin{array}{l}\text { Oil } \\
\text { products }\end{array}$ & Fuelwood & Hydroenergy $^{a}$ & $\begin{array}{l}\text { Imports of } \\
\text { electricity }\end{array}$ & $\begin{array}{l}\text { Coal and } \\
\text { coke }\end{array}$ & Peat & $\begin{array}{l}\text { Oil } \\
\text { shale }\end{array}$ & Total \\
\hline $\mathrm{TJ}$ & 50706 & 50475 & 34250 & 10162 & 6430 & 2761 & 2905 & 1456 & 159145 \\
\hline$\%$ & 31.9 & 31.7 & 21.5 & 6.4 & 4.0 & 2.0 & 1.6 & 0.9 & 100 \\
\hline
\end{tabular}

Source: [1].

a Hydro 10148 TJ and wind 14 TJ. 
much of this wood was used ineffectively [7]. In addition to the energy purposes, wood is also used for wood processing and exports.

The annual total consumption of energy went down $48 \%$ in the period 1990 to 1996 [17]. The gross energy-consumption went down a further $20 \%$ from 1996 to 2000. This is even more interesting, since the GDP (Gross Domestic Product) went up every year from 1996 to 2000 [2]. In this period, the mix of energy sources changed somewhat. The share of mazut (residual fuel oil) went down from $23.4 \%$ in 1996 to $6.6 \%$ in 2000 of gross energy consumption. At the same time, the share of natural gas in the gross energy-consumption went up from 20.3 to $31.7 \%$. The share of fuelwood stayed more or less the same with $22.7 \%$ in 1996 and $21.5 \%$ in 2000 [1].

Today Latvia uses renewable energy to a large extent. However, there is the potential to increase the utilisation of fuelwood. Latvia is an interesting example because the country does not have sufficient electricity-generating capacity. Also many heat plants are ineffective and in need of renewal or reconstruction.

The fact that Latvia has domestic renewable-energy resources makes it interesting because the utilisation of the domestic fuels would be sustainable both from an environmental and an economic point of view.

\section{Economic situation}

Latvia has a healthy economic development with growth rates higher than the average for the EU. The country is aiming at membership of the EU and has a strategy to reach the level of welfare corresponding to the standards of the developed countries $[6,15]$. At the same time, the country suffers from a negative trade balance - a negative economic factor shared with the other Eastern and Central European candidate countries [6].

Some of the economic indicators for Latvia can be seen in Table 2.

Since 1996, there has been a positive growth rate of GDP in Latvia [2]. Before this, the country was still suffering heavily from the shock of the independence and the rapid decline of the economy and industrial production. This changed in 1996, which was the first year with positive growth rate. The development continued in 1997 but in 1998 and especially 1999, the economy and the growth was adversely affected by the Russian crisis.

The fiscal situation is one of the problem areas in the Latvian national economy. The fiscal balance has been negative every year since 1995 except 1997. Despite this, the Government has invested in new projects in order to stabilise the aggregated demand. However, reduction of the fiscal deficit is one of the top priorities for the Latvian Government. At the same time, the Government is reducing the tax burden on business in order to improve the business environment [15].

Latvia has a negative trade-balance caused by the fact that the value of imports exceeds the value of exports. Unfortunately, imports continue to grow faster than exports. It can be calculated from reference [2] that the total imports were $82.3 \%$ higher in 2001 than in 1995 at current prices and the comparable number for exports was $129 \%$. 
Table 2

Economic indicators for Latvia

\begin{tabular}{llrrrrrrr}
\hline & & 1995 & 1996 & 1997 & 1998 & 1999 & 2000 & $2001^{\mathrm{a}}$ \\
\hline GDP & Million LVL & 2349.2 & 2829.1 & 3275.5 & 3589.5 & 3897 & 4340.6 & \\
GDPb & \% of prev. year & -0.8 & 3.3 & 8.6 & 3.9 & 1.1 & 6.8 & 7.5 \\
Fiscal balance & \% of GDP & -3.1 & -1.4 & 1.3 & -0.9 & -4.2 & -2.8 & -1.8 \\
Exports & Million LVL & 688.4 & 795.2 & 971.7 & 1068.9 & 1008.3 & 1131.3 & 1256.4 \\
Imports & Million LVL & 959.6 & 1278.2 & 1582.4 & 1881.3 & 1723.9 & 1933.9 & 2201.6 \\
Trade balance & Million LVL & -271.2 & -483.0 & -610.7 & -812.4 & -715.6 & -802.6 & -945.2 \\
Imports & \% of GDP & 40.8 & 45.1 & 48.4 & 52.4 & 44.2 & 44.6 & \\
Exports & \% of GDP & 29.3 & 28.1 & 29.7 & 29.8 & 25.9 & 26.0 & \\
Cent. Govt. Ex. Debt & Million LVLc & 216.6 & 227.3 & 218.4 & 231.5 & 359.0 & 348.0 & 456.7 \\
Cent. Govt. Ex. Debt & \% of GDP & 9.2 & 8.0 & 6.7 & 6.4 & 9.2 & 8.0 & \\
Av. Annual Inflation & \% & 25.0 & 17.6 & 8.4 & 4.7 & 2.4 & 2.6 & 2.5 \\
& & & & & & &
\end{tabular}

Sources: $[2,14,15]$.

a Forecast.

b Constant prices.

c End of period.

One of the best ways to improve the trade balance is to increase exports [3]. Exports can be increased by an increase in production of goods for exports. Another way to decrease the trade balance deficit is to import less. Let us now return to the energy system to analyse the possibilities to straighten the trade balance.

\section{Future energy supply—sustainable restructuring}

Sustainable development have been defined in many ways. See for example [10] for a discussion. A sustainable energy-system includes - as a minimum - that the pollution is lowered as much as possible. The pollution includes $\mathrm{CO}_{2}$ emissions, which will be emphasised here. Even though Latvia should be able to live up to the Kyoto targets, because of the decline in the economy, it should still take $\mathrm{CO}_{2}$ emission reductions seriously. In accordance with the Kyoto Protocol, Latvia individually or jointly has to ensure that its aggregate anthropogenic $\mathrm{CO}_{2}$ equivalent emissions of greenhouse gasses in the years 2008-2012 do not exceed 92\% of those for the year 1990 level [16]. For this goal to be reached, it is necessary "to introduce modern resource-saving technologies and to implement appropriate policy instruments" [16, p. 13]. Even if Latvia reaches a level below the target, it might be able to sell the $\mathrm{CO}_{2}$ credits [13].

Now I will attempt to combine the different aspects of the Latvian energy-system and the economy situation and hence develop a proposal for the future of energy supplies in Latvia that would benefit both the $\mathrm{CO}_{2}$ emission reduction and also the economy.

There are several ways to lower the $\mathrm{CO}_{2}$ emissions. One concerns the substitution of fuels. The $\mathrm{CO}_{2}$ emissions from coal are 100,000 ton/PJ, from fuel oil 74,000 ton/ PJ and from natural gas 57,000 ton/PJ [9]. From wood and other renewable energy 
sources, the $\mathrm{CO}_{2}$ emissions are balanced meaning there are no net emissions. This means that if fossil fuels are replaced with renewable energy sources, the $\mathrm{CO}_{2}$ emissions would be reduced substantially.

The second means to lower $\mathrm{CO}_{2}$ emissions concerns the production of heat and electricity. Here we should remember the future supply of electricity in Latvia and the present dependence on imported electricity from the neighbouring countries. As mentioned, a higher production of electricity in Latvia is important both because of supply security and because of economic uncertainty of continuing imports. Therefore, in order to develop domestic electricity supplies and less dependency on foreign imports, new production plants must be built in the country. A second thing to consider is that a system where heat and power are produced in combination is more effective than a system where heat and power are produced separately. When electricity is produced in traditional thermal plants, the heat that inevitably is produced is a waste product. By using this substantial amount of heat for district heating purposes, it is possible to reduce the use of fuels and thereby reduce the $\mathrm{CO}_{2}$ emission.

In relation to the economy and the use of fuels, there are also two things to consider. First there is the point that Latvia has to import all its fossil fuels. This means that the trade balance is affected negatively. Secondly it should be remembered that Latvia has a significant potential for increasing the use of domestic energy sources in the form of renewable fuel-wood. An increase of the utilisation of domestic energy sources would mean that it would be possible to reduce the import of fossil fuels. This would affect the trade-balance positively.

An additional important thing to consider when dealing with the economy is the production of the machinery to produce the heat and electricity, here called energy technology. If the energy technology is imported, the trade balance is affected negatively. If the energy technology is produced in Latvia, it would mean that it would not have to be imported. So domestic production of energy technology means that the trade balance is affected positively. One more point concerning this issue is the possibility that Latvia would be able to produce energy technology, which could be exported. This would also affect the trade balance positively.

A conclusion is that to reduce $\mathrm{CO}_{2}$ emissions and at the same time reduce the trade balance deficit, Latvia could do three things. (1) substitute the use of imported fossil fuels with domestic renewable energy sources, (2) produce heat and electricity in combination, and (3) produce the energy technology that is necessary for producing heat and electricity.

\section{Production of energy technology}

In Latvia, there is a long tradition for producing boilers, which are one of the components in boiler houses also called heat plants. In the time before the Latvian independence, different kinds of production companies were placed in Latvia because of the infrastructure and the skilled specialists [12]. Before 1991, Latvia produced boiler houses and the production has continued after independence [8]. 
Today there are two main producers of boiler houses in Latvia. One of them produces boilers up to $2.5 \mathrm{MW}$ and the other produces boilers between 2 and $10 \mathrm{MW}$. The boilers are all capable of using different kinds of wood as fuel. The manufacturers are able to deliver all the components for a boiler house. For the time being, there are no problems with the attraction of customers, which are the municipalities in Latvia. Some of these contact the manufacturers when they need and are able to finance a new boiler house or a renovation of the existing boiler-house [8].

Innovation in the boiler-house production companies takes place from one customer to another, meaning there is no innovation policy, but the product line is improved incrementally from one delivery to the next. However, many of the customers are not interested in state-of-the-art technology. Rather they want low-technology systems each with a manual-working wood supply. The reason for this is that automatic feeding is more expensive and the customers in the municipalities cannot afford this. However, they can afford the wages for the manual workers at the boiler plants because the wages are low $[7,8]$.

The Latvian boiler manufacturers do not produce co-generation plants because there are no customers at present in Latvia for such technology. Both the boiler producers and the municipalities express insecurities about the price for electricity that can be obtained in the future $[7,8]$.

Another aspect is that co-generation fuelled by renewable fuelwood is a technology that is still being developed. This means that an innovation process must take place. In order for the Latvian companies to make a more substantial innovation process, a number of things are needed. Firstly there has to be a market for the products, either in the short term or in the long term. The technology must be developed and implemented - either by importing technology or by domestic innovation. A possibility could be joint ventures with foreign companies in order to make a transfer of knowledge to Latvia to enhance the capacities that already exist in the country.

Secondly the municipalities need to be sure of the future economy of the projects and they have to be able to finance them.

\section{Conclusions}

Formerly part of the Soviet Union, the Latvian energy-system is based on imported electricity and unreliable hydro power and a few co-generation plants. At the same time, the country has substantial biomass resources, since app. $45 \%$ of Latvia is covered with woods. The large area of woods gives a considerable potential for utilising the waste wood as an energy resource without harming the woods.

There is a need to find alternatives to the import of electricity and increase the domestic production of electricity in Latvia. In order not to become more dependent on other countries, it is essential that Latvia utilises its own biomass-energy resource.

This is an opportunity not to be missed for Latvia to achieve an economic, sustainable energy-supply. This is done by using domestic renewable energy resources and using the knowledge that already exists in the country about producing energy 
technology and to co-operate with foreign companies and institutions to develop technologies adapted to the local conditions in Latvia.

An increased domestic production of biomass electricity and energy technology would not only be of importance to the energy system, but would also strengthen the national economy. It would reduce the import of fossil fuels, electricity and energy technology and thereby reduce the trade-balance deficit.

\section{References}

[1] Central Statistical Bureau of Latvia. Energy Balance 2000. Riga 2001.

[2] Central Statistical Bureau of Latvia. Press releases 31.01.2002, 07.03.2002.

[3] Christensen TA, Christiansen J, Pedersen H. National Economy in Denmark. Samfundslitteratur, 7th ed. 2000 [in Danish].

[4] Danish Energy Agency. Energy statistics 2000. Copenhagen; 2000 [in Danish].

[5] Ekmanis Y, Zebergs V. Present situation and opportunities for the energy sector development in the Baltic states. Latvian Journal of Physics and Technical Sciences 2000;4:3-10.

[6] Eurostat. EU enlargement - key data on the candidate countries. News release No. 129/2001.

[7] Interviews and meetings with municipalities in Latvia: Juliana Rozhkova and Valdis Bronics, Municipal Directors, Viesite, 15 March 1999; Mayor Andris Rancans and Deputy Mayor Ralf Salmo, Liepa, 16 March 1999; Eigils Kuzis Regional Planner, Saldus, 17 March 1999; Mayor Janis Pavlovics and Technical Director Normunds Ozolins, Olaine 24 September 2001. Including showings of the boiler plants.

[8] Interviews with boiler and heat-plant producers in Latvia: President Edgars Chapus, Valpro Corporation, 16 March 1999; Director Karlis Zarins and Technical Director Ivars Bernavs, Orions, 18 March 1999; Technical Director Ivars Bernavs, Orions, 27 September 2001; President Atis Zirdzins, Komforts, 28 September 2001.

[9] Meyer NI, Nørgård JS, Galster G, Guldbrandsen T. Energy and resources - for sustainable development. Polyteknisk Forlag, 2nd ed. 1994 [in Danish].

[10] Lafferty WM, Langhelle O. Sustainable development. In: Lafferty WM, Langhelle O, editors. Sustainable development. Oslo: Gyldendal Ad Notam; 1995 [in Norwegian].

[11] Latvenergo. Annual Report 2000. Riga, 2001.

[12] The Latvian Institute. History of Latvia. Riga, 2001.

[13] Lund H, Hvelplund F, Kass I, Dukalskis E, Blumberga D. District heating and market economy in Latvia. Energy 1999;24:549-59.

[14] Ministry of Economy. Economic Development of Latvia. Riga, December 1998.

[15] Ministry of Economy. Economic Development of Latvia. Riga, December 2001.

[16] Ministry of Environmental Protection and Regional Development. Climate Change Mitigation Policy Plan for Latvia. Riga, 1998.

[17] Shipkovs P, Kashkarova G, Shipkovs M. Renewable-energy utilization in Latvia. Renewable Energy 1999;16:1241-4. 